\title{
1 Nitrate amendment to control sulphide accumulation in shrimp ponds
}

2 Funda Torun ${ }^{\mathrm{a}}$, Bárbara Hostins ${ }^{\mathrm{b}}$, Jessica Teske $^{\mathrm{b}}$, Peter De Schryver $^{\mathrm{b}}$, Nico Boon $^{\mathrm{a}}$, Jo De Vrieze $^{\mathrm{a}}$

$3{ }^{\mathrm{a}}$ Center for Microbial Ecology and Technology (CMET), Ghent University, Coupure Links 653, Ghent

49000 , Belgium

5 b INVE Technologies NV, Hoogveld 93, Dendermonde, Belgium

$6 \quad *$ Address correspondence to Nico Boon, Nico.Boon@UGent.be. Telephone number: +32 9/264 5976 
7

8

9

\section{Abstract}

The production of shrimp is often performed in earthen outdoor ponds in which the input of feed and faeces on the bottom results in deterioration of the water quality that results in a negative impact on the aquatic animals and the environment.

Nitrate application in shrimp ponds could improve pond water and sediment quality by oxidizing anaerobic zones of the sediment. This study was conducted to evaluate the possible benefits of nitrate treatment in combination with probiotics application to decrease sulphide formation in shrimp ponds, which is a crucial problem during the growth phase of shrimp. A batch system including shrimp feed and faeces, representing the bottom waste produced during 90 days of shrimp culture, was used to test the effect of nitrate addition under anaerobic conditions that mimic the dead zones in shrimp pond bottoms where high amounts of organic matter accumulate. Nitrate addition acted as a curative solution for hydrogen sulphide $\left(\mathrm{H}_{2} \mathrm{~S}\right)$ accumulation, rather than preventive. Nitrate amended treatments (12.5 mg/L.day $\mathrm{NO}_{3}$ ) decreased the accumulated $\mathrm{H}_{2} \mathrm{~S}$ in the headspace of incubation bottles by $93 \pm 3 \%$ compared to the controls. Nitrate addition increased $\mathrm{pH}$ and decreased organic acids accumulation to trace amounts. The use of a denitrifying strain did not improve the beneficial effect of nitrate, indicating that intrinsic capacity for anoxic conversion of waste by the present community was sufficient. In conclusion, nitrate treatment showed a curative potential to control $\mathrm{H}_{2} \mathrm{~S}$ accumulation in the shrimp ponds that is a critical problem during the growth of shrimp.

Keywords: nitrate treatment, probiotic, shrimp pond, sulfide, water quality 


\section{Introduction:}

Fish and shrimp are an essential source of proteins for humans. About $50 \%$ of all aquatic animal protein originates from aquaculture, a number that should increase with an additional $10 \%$ by 2030 to keep on feeding the growing human population (FAO, 2018). The production of shrimp is usually performed in outdoor ponds with a surface area of a few thousand $\mathrm{m}^{2}$ up to several hectares. The shrimp grow in the pond for a period of about 3 months until they reach harvest size of around $15 \mathrm{~g}$ or more (Hung and Quy, 2013). These ponds are constructed either as earthen ponds, with a direct continuous contact between culture water and bottom sediment, or as lined ponds where a plastic type material (e.g., high density polyethylene) is placed above the earthen bottom, thereby minimizing contact between the culture water and the soil (Pralitwilaikul et al., 2006). In both earthen and lined ponds, there is a high input of organic material (OM) to the pond bottom from uneaten feed and digested feed (faeces) in combination with dead material (e.g., shrimp shedding). This dense layer of organic matter accumulation can reach up to $7.5-10 \mathrm{~cm}$ per growing season (Avnimelech and Ritvo, 2003).

The organic-rich conditions on the pond bottom in combination with the typical temperatures of 25-30 ${ }^{\circ} \mathrm{C}$ in shrimp ponds promote microbial activity, which substantially influences water quality and overall shrimp health. Under aerobic conditions, the mineralisation of OM and the release of carbon dioxide, ammonia and other nutrients stimulates phytoplankton growth, which is advantageous for shrimp growth, since they serve as the main food for zooplankton and benthic organisms, which, in turn, become the food of shrimp (Burford et al., 1998).

Aerobic microbial activity at the pond bottom, however, can become so high that the rate of oxygen consumption exceeds the rate of oxygen transfer from pond water to pore water of the sediment, and oxygen gets depleted at the water-sediment interphase (Boyd, 2003). Anaerobic processes then take over, leading to release of potentially toxic metabolites, such as organic acids, reduced organic sulphur compounds, reduced manganese and hydrogen sulphide (Avnimelech and Ritvo, 2003).

Hydrogen sulphide $\left(\mathrm{H}_{2} \mathrm{~S}\right)$ and iron sulphide create a bad odour and black colour of the sediment, respectively, and pose a toxicological risk for the shrimp that naturally dwell and feed on the pond bottom (Boyd, 1998; Avnimelech and Ritvo 2003). Sulphide toxicity depends on the $\mathrm{H}_{2} \mathrm{~S}$ concentration (i.e., $\mathrm{pH}$ dependent), and varies between the different species and growth phase of the shrimp (Vismann, 
1996; Panakorn, 2016). For toxicity testing, a $48 \mathrm{~h} \mathrm{LC50}$ value of $0.0087 \mathrm{mg} / \mathrm{L} \mathrm{H}_{2} \mathrm{~S}$ was reported for Pacific white shrimp (L. vannamei) post-larvae, while for juveniles this was $0.0185 \mathrm{mg} / \mathrm{L}$ (Federal Register, 2010) and for black tiger shrimp (P. monodon) it was $0.033 \mathrm{mg} / \mathrm{L}$ (Chen, 1985). Suo et al. (2017) found that chronic exposure to sub-lethal levels (1/10 of 96-hour LC50) could lead to a damage of the gut structure, stimulate the response of the inflammatory and immune systems, and change the structure of gut microbiota in L. vannamei. Sulphide also inhibits nitrification (Joye and Hollibaugh, 1995), and, thereby, increases ammonium accumulation in the pond.

Current approaches to control waste accumulation and its negative effects in ponds are limited. In most cases, mechanical manipulation is used to remove and/or oxidize the sludge, a labour-intensive approach, which is to be applied in between shrimp grow-out cycles during a dry period in the ponds. A number of probiotic products are suggested to improve water and sediment quality, yet, so far no highquality scientific proof is available on their potential (Antony and Filip, 2006; Martinez Cruz et al.,2012;, Boyd, 2014 ).

Among the approaches applied, sodium nitrate has been widely used by farmers as a fertilizer, water quality conditioner and bottom soil oxidant in pond culture of L. vannamei. Nitrate application could improve pond water and sediment quality by enhancing denitrification and the composition of phytoplankton communities. Nitrate is the preferred electron acceptor for bacteria under oxygen deficient conditions. Nitrate addition may control sulphate reduction by replacing sulphate reducing bacteria (SRB) with denitrifying bacteria through interspecies competition (Hubert and Voordouow, 2007), inhibition of dissimilatory sulphite reductase with the nitrite produced through nitrated reduction (Greene et al., 2006) or a metabolic switch of certain SRB that prefer nitrate over sulphate as terminal electron acceptor (Schwermer et al., 2010). Nitrate application to the aquaculture ponds was reported to stabilize the redox potential, oxidizing anaerobic zones that might lead to the production of hydrogen sulphide and other potentially toxic microbial metabolites (Avnimelech and Zohar 1986, Chainark and Boyd, 2010). Yet, despite the nitrate treatment for wastewater studies in recirculating marine aquaculture systems (Tal et al., 2009; Schwermer et al., 2010; Christianson et al., 2015), to best of our knowledge, no peer-viewed study described the direct impact and mechanism of nitrate treatment to control sulphide accumulation in traditional shrimp aquaculture ponds. 
The objective of this study was to investigate the capacity and the mechanism of curative and preventive nitrate amendment, including its application together with a probiotic, to control $\mathrm{H}_{2} \mathrm{~S}$ accumulation at the shrimp pond bottom. The probiotic strain, Bacillus licheniformis was used for its documented use in L. vannamei culture and for its denitrification capacity (Kim et al., 2005; Li et al., 2007).

\section{Materials and Methods:}

\subsection{Feed and faeces collection and storage}

Shrimp faeces were collected directly from the flush outlet of shrimp tanks where $L$. vannamei at post-larvae phase were fed with CreveTec grower 2 (CreveTec, Ternat, Belgium), at the facilities of the Aquaculture and Artemia Reference Center, Ghent University, Belgium. For each experiment, new and fresh batches of faeces were used to avoid degradation during storage. The $\mathrm{pH}$ and conductivity of the faeces solution was measured directly upon arrival in the lab. Samples for total solids (TS) and volatile solids (VS) measurements were stored at $4{ }^{\circ} \mathrm{C}$ until use. The CreveTec grower 2 was also used as dosed feed, and stored at $-20{ }^{\circ} \mathrm{C}$ until addition.

\subsection{Experimental set-up and operation}

\subsubsection{Dual dose nitrate treatment}

The addition of three different nitrate concentrations $\left(50,100,200 \mathrm{mg} / \mathrm{L} \mathrm{NO}_{3}^{-}\right)$as sodium nitrate (Carl Roth GmbH \& Co.KG, Karlsruhe, Germany) to improve water quality in the shrimp ponds was evaluated under anaerobic conditions. Glass Schott bottles (Duran Group GmbH, Mainz, Germany) with a total volume of $500 \mathrm{~mL}$, closed with airtight lids using rubber stoppers, were used for this experiment for the pond model batch set-up. The headspace of the bottles was flushed with nitrogen gas to replace air for ensuring anaerobic conditions. The presence of the shrimp and accumulated waste was represented by supplementing feed and faeces in the batch culture. Each treatment consisted of three biological replicates, including the controls $(\mathrm{N}-0)$ without any $\mathrm{NO}_{3}{ }^{-}$supplementation, and received 392 $\pm 1 \mathrm{mg}$ feed and $12.9 \mathrm{~mL}$ (4\% dry weight) faeces in a final volume of $300 \mathrm{~mL}$ artificial sea water (Instant Ocean, Aquarium Systems, Mentor, OH, USA) to achieve the final concentration of $2.87 \mathrm{~g} / \mathrm{L}$ total waste as feed and faeces (Table 1). The salinity of the artificial sea water was adjusted to $20 \mathrm{~g} / \mathrm{L}$. The amount 
of feed and faeces were calculated based on dry weight of the cumulative waste of 90 days of shrimp culture at a stocking density of $50 \mathrm{shrimp} / \mathrm{m}^{3}$ using feeding tables (Supplementary Information, Table 1). It represents a growth cycle in shrimp grow-out ponds, assuming all the waste accumulated in the lower $10 \mathrm{~cm}$ water column. About $25 \%$ of cumulative input feed was assumed to be accumulating in the pond bottom, with $15 \%$ considered digested feed (faeces), while $10 \%$ was uneaten feed. All treatments and the control were incubated for 66 days in a temperature-controlled room at $28 \pm 1^{\circ} \mathrm{C}$ without shaking.

The $\mathrm{NO}_{3}{ }^{-}$was supplemented on day 0 and day 14 in three different concentrations, i.e., $50(\mathrm{~N}$ 50), $100(\mathrm{~N}-100)$ and $200(\mathrm{~N}-200) \mathrm{mg} / \mathrm{L} \mathrm{NO}_{3}{ }^{-}$, using a sterile syringe and needle. The overhead gas pressure was measured every 2-4 days with an UMS-Tensiometer (Infield 7) device (UMS, Munchen, Germany), using a needle pierced through the rubber septum, and reported at standard temperature and pressure (STP, 273K and 101,325 Pa) conditions. Gas and liquid samples were collected through the rubber septum of all replicates. The gas samples were analysed immediately, while liquid samples were collected from the same data points, filtered over a $0.20 \mu \mathrm{m}$ Chromafil ${ }^{\circledR}$ Xtra filter (Macherey-Nagel, PA, USA), and stored in the fridge $\left(4^{\circ} \mathrm{C}\right)$, prior to analysis for nitrate, nitrite and sulphate concentrations. Organic acids samples were evaluated immediately after sampling at the end of the experiment.

\subsubsection{Multiple dose nitrate treatment}

Three different treatments with lower concentrations of nitrate at $12.5(\mathrm{~N}-12.5), 25(\mathrm{~N}-25), 50$ $(\mathrm{N}-50) \mathrm{mg} / \mathrm{L} \mathrm{NO}_{3}{ }^{-}$) were tested in the same anaerobic set-up with addition of the respective concentrations of $\mathrm{NO}_{3}{ }^{-}$every 4 days in contrast to the previous test where only dual dose applied. Each treatment consisted of three biological replicates, and was supplemented with $391 \pm 1 \mathrm{mg}$ feed and 13.87 $\mathrm{mL}$ faeces (dry weight $3.7 \%$ ) in a $300 \mathrm{~mL}$ instant ocean solution to achieve the final concentration of $2.87 \mathrm{~g} / \mathrm{L}$ total waste (see section 1.2.1). Treatments and the control were incubated for 56 days under anaerobic conditions in a temperature-controlled room at $28 \pm 1{ }^{\circ} \mathrm{C}$ without shaking. Gas and liquid samples were collected and analysed in the same way as the previous test (section 2.2.1).

\subsubsection{Microbially assisted nitrate treatment}

For this experiment, a nitrate treatment at $50 \mathrm{mg} / \mathrm{L} \mathrm{NO}_{3}{ }^{-}$with and without addition of Bacillus licheniformis spores at $10^{7} \mathrm{CFU} / \mathrm{mL}$ as a probiotic strain was tested in the same set-up as section 2.2.1 
and 2.2.2. Bacillus licheniformis was provided by INVE Aquaculture and is the strain used in the probiotic product Sanolife PRO-W. Similar to previous tests, each bottle contained $392 \pm 1 \mathrm{mg}$ feed and $11.34 \mathrm{~mL}$ faeces ( $4.6 \%$ dry weight) in a total volume of $300 \mathrm{~mL}$ of instant ocean to achieve final concentration of $2.87 \mathrm{~g} / \mathrm{L}$ total waste (same as previous tests), and was incubated under anaerobic conditions in a temperature controlled room at $28 \pm 1^{\circ} \mathrm{C}$ for 44 days until the stability of the system was observed. The test was conducted in three biological replicates and included the treatment with only Bacillus licheniformis without $\mathrm{NO}_{3}{ }^{-}$addition (B), the treatment with only $50 \mathrm{mg} / \mathrm{L} \mathrm{NO}_{3}{ }^{-}$without $B$. Licheniformis addition $(\mathrm{N})$, the treatment with $50 \mathrm{mg} / \mathrm{L} \mathrm{NO}_{3}{ }^{-}$and $B$. Licheniformis addition $(\mathrm{B}+\mathrm{N})$ and a control without any $B$. licheniformis or $\mathrm{NO}_{3}{ }^{-}$addition (C).

The $\mathrm{NO}_{3}{ }^{-}$was supplemented every 4 days in a similar operation to the previous test with multiple dose $\mathrm{NO}_{3}{ }^{-}$treatment. Gas and liquid samples were collected and analysed in the same way to previous tests (section 2.2.1 and 2.2.2).

\subsubsection{Comparison of nitrate and sodium hydroxide treatments}

To compare the impact of nitrate and base treatments on $\mathrm{pH}$ increase and $\mathrm{H}_{2} \mathrm{~S}$ production and to better understand the impact of $\mathrm{pH}$ on sulphur speciation, the same set-up that included $390 \pm 1 \mathrm{mg}$ feed and $13.23 \mathrm{~mL}$ faeces $(3.9 \%$ dry weight) in a total volume of $300 \mathrm{~mL}(2.87 \mathrm{~g} / \mathrm{L}$ total waste $)$ was used. The test bottles were incubated under anaerobic conditions in a temperature controlled room at $28 \pm 1^{\circ} \mathrm{C}$ for 8 days. The test was conducted in three biological replicates and included treatments with $200 \mathrm{mg} / \mathrm{L}$ $\mathrm{NO}_{3}{ }^{-}$and treatments with $1 \mathrm{M}$ sodium hydroxide $(\mathrm{NaOH})$ addition until $\mathrm{pH}$ reached above 8 (final concentation to reach target $\mathrm{pH}$ was $320 \mathrm{mg} / \mathrm{L} \mathrm{NaOH}$ ). The $\mathrm{NaOH}$ and $\mathrm{NO}_{3}^{-}$treatments were supplemented only on day 5 when an accumulation of $\mathrm{H}_{2} \mathrm{~S}$ was measured. Gas and liquid samples were collected and analysed in the same way to previous tests.

\subsection{Analytical techniques}

The TS and VS were determined according to Standard Methods (Greenberg et al. 1992). The pH was measured with a pH meter (Methroohm, Herisau, Switzerland). The conductivity was measured with a conductivity electrode (Consort C532, Turnhout, Belgium) at the start and the end of the experiment. The headspace gas composition was analysed on a compact GC (Global Analyser Solutions, 
Breda, the Netherlands). In the first channel, $\mathrm{O}_{2}, \mathrm{~N}_{2}, \mathrm{CH}_{4}$ and $\mathrm{H}_{2}$ (Porabond Q pre-column and Molsieve 5A column) were measured, while in the second channel (Rt-QS-bond column and pre-column) $\mathrm{CO}_{2}$, $\mathrm{N}_{2} \mathrm{O}$ and $\mathrm{H}_{2} \mathrm{~S}$ were determined with a thermal conductivity detector that has a lower detection limit of 100 ppmv for each gas component. The concentrations of nitrate, nitrite and sulphate were determined with ion chromatography (930 Compact IC Flex, Metrohm, Herisau, Switzerland), equipped with a Metrosep A supp 5-150/4.0 column and conductivity detector, after diluting the samples 1:50 using ultra-pure water (Milli-Q, Millipore Corparation, Burligton, MA, USA). The detection limit was of 0.05 to $200 \mathrm{mg}$ ion/L. Organic acid concentrations, i.e., formate, acetate, propionate, butyrate and isobutyrate, were determined with organic acids chromatography (930 Compact IC Flex, Metrohm, Herisau, Switzerland), equipped with a Metrosep Organic acids 250/7.8 (61005200) column, inline bicarbonate removal (MCS) and an 850 IC conductivity detector with a detection limit of $0.5-2000 \mathrm{mg} / \mathrm{L}$.

\subsection{Statistical analyses}

One-way analysis of variance (ANOVA) was used to determine the significant differences in water quality parameters among treatments, following the verification of homogeneity of the data (Levene's test) using IBM SPSS Statistics 25 software. If the assumption of homogeneity of the variances is found not tenable, a Welch test is used. The ANOVA and Welch tests were followed by Tukey's post-hoc comparison when significant differences were observed. Statistical significance was considered at $\mathrm{P}<$ 0.05 .

\section{Results}

\subsection{Dual dose nitrate treatment}

The addition of three different $\mathrm{NO}_{3}{ }^{-}$concentrations $\left(50,100\right.$ and $200 \mathrm{mg} \mathrm{NO}_{3}{ }^{-} / \mathrm{L}$, further indicated as $\mathrm{N}-50, \mathrm{~N}-100, \mathrm{~N}-200$, respectively) was evaluated in comparison to a control without any supplemented $\mathrm{NO}_{3}{ }^{-}(\mathrm{N}-0)$, all tested under anaerobic conditions. The $\mathrm{NO}_{3}{ }^{-}$addition for the respective concentrations was conducted on day 0 and 14 during the test. After the first dose of $\mathrm{NO}_{3}{ }^{-}$, all the supplemented $\mathrm{NO}_{3}{ }^{-}$was consumed in the first 2 days, yet it did not prevent $\mathrm{H}_{2} \mathrm{~S}$ accumulation except delaying $\mathrm{H}_{2} \mathrm{~S}$ production for the N-200 treatment (Fig 1A and 1C). Four days after the second dose of nitrate addition (day 18), $23 \pm 4 \%, 53 \pm 2 \%$ and $86 \pm 6 \%$ less accumulated $\mathrm{H}_{2} \mathrm{~S}$ was measured for the 
N50, N100 and N200 treatments, respectively, as compared to the control ( $<<0.0001)$. When the $\mathrm{NO}_{3}^{-}$ was consumed, $\mathrm{H}_{2} \mathrm{~S}$ accumulated again, and at the end of the incubation time (day 66), in the N-50, N100 and $\mathrm{N}-200$ treatments, $10 \pm 1 \%, 19 \pm 0 \%$ and $33 \pm 7 \%$, respectively, less accumulated $\mathrm{H}_{2} \mathrm{~S}$ was measured compared to the control. According to Tukey test, compared to the control, this difference was significant for $\mathrm{N} 100$ and $\mathrm{N} 200$ treatments ( $\mathrm{p}=0.04$ and $\mathrm{p}<0.0001$, respectively). A similar trend was observed in $\mathrm{CO}_{2}$ concentrations after the second dose of $\mathrm{NO}_{3}{ }^{-}$on day 14 , with a decline in accumulated $\mathrm{CO}_{2}$. On day 18 , in the $\mathrm{N}-50, \mathrm{~N}-100$ and $\mathrm{N}-200$ treatments, $15 \%, 44 \pm 3 \%$ and $74 \pm 9 \%$ less $\mathrm{CO}_{2}$ was observed compared to the controls (Figure 1B). Likewise, after all $\mathrm{NO}_{3}{ }^{-}$was consumed, $\mathrm{CO}_{2}$ started to increase again.

At the beginning of the experiment, until all $\mathrm{NO}_{3}{ }^{-}$was consumed (Figure $2 \mathrm{~A}$ ), the concentration of nitrite measured was higher than the safe limits (approximately $6 \mathrm{mg} / \mathrm{L} \mathrm{NO}_{2}-\mathrm{N}$ ) indicated for culture of shrimp in ponds, however, the concentrations dropped after day 4 (Supplementary Information, Figure 1). Sulphate concentrations showed a decreasing profile for all the treatments during incubation. A slightly lower reduction in sulphate concentrations was measured in the N-200 treatment (Figure 1D), but at the end of the incubation time no significant difference could be reported $(\mathrm{p}=0.220)$. Although there was a $\mathrm{H}_{2} \mathrm{~S}$ decline in $\mathrm{N}-200$ treatment between day 14 to 18 (Figure 1A), this change was not observed in the sulphate concentrations.

Similarly, by the end of incubation time, compared to the control, $18 \pm 9 \%, 59 \pm 4 \%$ and $80 \pm 12 \%$ less total organic acids were measured in the N-50, N-100 and N-200 treatments, respectively (Table 2). A slight $\mathrm{pH}$ increase was observed in treatments in comparison to the controls $(\mathrm{p}<0.0001)$ (Table 2). The initial $\mathrm{pH}$ was $7.05 \pm 0.01$ for all the treatments and the controls. At the end of the incubation time, the $\mathrm{N}-200$ treatment had the highest $\mathrm{pH}(7.40 \pm 0.02)$, while the control $\mathrm{pH}$ remained similar to the initial $\mathrm{pH}$. The conductivity of N-50 treatments and the control did not show a significant difference, but there was a slight increase for the $\mathrm{N}-100$ and $\mathrm{N}-200$ treatments $(\mathrm{p}=0.017$ and $\mathrm{p}=0.001$, respectively according to Tukey test compared to the control) (Supplementary Information, Table 2). 


\subsection{Multiple dose nitrate treatment}

This test was conducted to overcome the limitation of $\mathrm{NO}_{3}{ }^{-}$as the electron donor, since all added $\mathrm{NO}_{3}{ }^{-}$was consumed within first 4 days in the dual dose test. Supplementation of three different $\mathrm{NO}_{3}{ }^{-}$ concentrations every 4 days at lower concentrations than the previous test $(\mathrm{N}-12.5, \mathrm{~N}-25, \mathrm{~N}-50)$ were evaluated in comparison to a control (N-0). A curative effect was observed after 20 days with frequent supplementation of $\mathrm{NO}_{3}{ }^{-}$every 4 days (Figure $2 \mathrm{~A}$ ). Since there was no $\mathrm{NO}_{3}{ }^{-}$limitation in the treatments, by the end of the incubation time they yielded $20 \pm 0 \%, 41 \pm 9 \%$ and $95 \pm 1 \%$ of less $\mathrm{H}_{2} \mathrm{~S}$ in the headspace compared to the control. Hence, the treatment with $50 \mathrm{mg} / \mathrm{L} \mathrm{NO}_{3}{ }^{-}$was the most effective dose to control $\mathrm{H}_{2} \mathrm{~S}$ accumulation (Figure 2A). In parallel to the dual test, the $\mathrm{CO}_{2}$ concentrations had showed a similar trend as the $\mathrm{H}_{2} \mathrm{~S}$ concentrations (Figure 2B).

The supplemented $\mathrm{NO}_{3}{ }^{-}$was consumed in first 2 days in the beginning of the experiment (Figure 2C). This was similar to the dual dose test. The $\mathrm{NO}_{3}{ }^{-}$uptake stopped around day 52 for $\mathrm{N}-50$ treatment and $\mathrm{NO}_{3}{ }^{-}$started to accumulate. Nitrite concentration remained in most cases under detection limit, but the $\mathrm{N}-50$ treatment had over $6 \mathrm{mg} / \mathrm{L} \mathrm{NO}_{2}-\mathrm{N}$ on day 52 (Supplementary Information, Figure 2). There was no significant difference in $\mathrm{SO}_{4}{ }^{2-}$ concentrations between the treatments and the control $(\mathrm{p}=0.372)$.

With frequent supplementation of nitrate, the removal of organic acids was also enhanced. By the end of the incubation time, $54 \pm 9 \%, 97 \pm 2 \%$ and $98 \pm 1 \%$ less total organic acids were measured in the $\mathrm{N}$ $12.5, \mathrm{~N}-25$ and $\mathrm{N}-50$ treatments, respectively, compared to the control (Table 3). The rise in $\mathrm{pH}$ in the treatments was significantly higher $(\mathrm{p}<0.0001)$ (Table 3$)$. The initial $\mathrm{pH}$ of the treatments was 7.05 \pm 0.01 . At the end of the incubation time, $\mathrm{N}-12.5, \mathrm{~N}-25$ and $\mathrm{N}-50$ treatments had $\mathrm{pH}$ of $7.69 \pm 0.01$, $7.90 \pm 0.06,8.78 \pm 0.03$ respectively, while the control had a $\mathrm{pH}$ of $7.45 \pm 0.05$. The conductivity at the end of the experiment was very similar between the treatments but they were slightly larger than the control $(\mathrm{p}=0.03)($ Supplementary Information, Table 3$)$.

\subsection{Microbially assisted nitrate treatment}

A curative effect for $\mathrm{H}_{2} \mathrm{~S}$ accumulation was observed after 20 days with frequent supplementation of $50 \mathrm{mg} / \mathrm{L} \mathrm{NO}_{3}{ }^{-}$every 4 days (same as section 3.2). There was no significant impact of sole B.licheniformis treatment to control $\mathrm{H}_{2} \mathrm{~S}$ accumulation (Tukey HSD, comparison between control and 
B treatment, $\mathrm{p}=0.836$ ). The $50 \mathrm{mg} / \mathrm{L} \mathrm{NO}_{3}{ }^{-}$treated incubations ( $\mathrm{N}$ and $\mathrm{N}+\mathrm{B}$ treatments) yielded $3.8 \pm 0.8$ and $3.4 \pm 0.7 \mathrm{mg} \mathrm{S} / \mathrm{L} \mathrm{H}_{2} \mathrm{~S}$ in the headspace of the treatment vials by the end of the incubation time, while controls and sole B.licheniformis treatment had $56.2 \pm 0.8$ and $57 \pm 1.6 \mathrm{mg} \mathrm{S} / \mathrm{L} \mathrm{H}_{2} \mathrm{~S}$, respectively (Figure 3A). The $\mathrm{CO}_{2}$ concentrations followed a similar trend as the $\mathrm{H}_{2} \mathrm{~S}$ concentrations (Figure 3B).

Similar to previous experiments, the added $\mathrm{NO}_{3}{ }^{-}$in the beginning was consumed in the first 2 days, and despite the frequent $\mathrm{NO}_{3}{ }^{-}$addition every 4 days, no detectable $\mathrm{NO}_{3}{ }^{-}$accumulation was measured in the liquid samples until day 36 when the system reached the saturation of the $\mathrm{NO}_{3}{ }^{-}$uptake (Figure $3 \mathrm{C})$. Sulphate concentrations did not show a significant difference $(\mathrm{p}=0.828)$ between the treatments and the control (Figure 3D).

The $\mathrm{NO}_{3}{ }^{-}$supplemented treatments decreased total organic acids accumulation to trace amounts of butyrate, while formate, acetate and propionate went below detection limit $(\mathrm{p}<0.0001)$. Initial $\mathrm{pH}$ was $7.41 \pm 0.02$ for all incubations. At the end of the incubation time, an increase in $\mathrm{pH}$ was measured with $\mathrm{NO}_{3}{ }^{-}$supplemented treatments when $\mathrm{pH}$ reached $8.09 \pm 0.03$ and $8.08 \pm 0.03$ for $\mathrm{N}$ and $\mathrm{N}+\mathrm{B}$ treatments, respectively, while the control and only probiotic added treatments retained a $\mathrm{pH}$ around $7.26 \pm 0.03$ and $7.22 \pm 0.02$ (Table 4). There was no significant difference in conductivity between the treatments and the control ( $\mathrm{p}=0.276)$ (Supplementary Information Table 4).

\subsection{Comparison of nitrate and sodium hydroxide treatments}

A short test was performed to compare the impact of a base and nitrate addition on $\mathrm{pH}$ change and $\mathrm{H}_{2} \mathrm{~S}$ production. On day 5, when $\mathrm{H}_{2} \mathrm{~S}$ production reached 30.1 $\pm 2.7 \mathrm{mg} / \mathrm{L}, \mathrm{NO}_{3}{ }^{-}$and sodium hydroxide $(\mathrm{NaOH})$ addition was performed (Supplementary Information, Figure 4). While the control continued producing $\mathrm{H}_{2} \mathrm{~S}$ (on day $9,41.7 \pm 0.7 \mathrm{mg} / \mathrm{L} \mathrm{H}_{2} \mathrm{~S}$ ), $\mathrm{NaOH}$ supplemented treatments showed a stabile $\mathrm{H}_{2} \mathrm{~S}$ concentration $(29.7 \pm 0.5 \mathrm{mg} / \mathrm{L})$, but $\mathrm{NO}_{3}{ }^{-}$supplemented treatment resulted in a significant decline, and reached $3.5 \pm 1.3 \mathrm{mg} / \mathrm{L} \mathrm{H}_{2} \mathrm{~S}(\mathrm{p}<0.0001)$.

The initial $\mathrm{pH}$ was $7.02 \pm 0.02$ for all incubations. Just after addition of the treatments, the $\mathrm{pH}$ of $\mathrm{NaOH}$ supplemented treatment reached of $8.66 \pm 0.02$ but for $\mathrm{NO}_{3}{ }^{-}$supplemented treatment, this value 
was 7.29 \pm 0.08 . At the end of the experiment, the $\mathrm{NaOH}$ treatment had a $\mathrm{pH}$ of $7.59 \pm 0.01$ and the $\mathrm{NO}_{3}{ }^{-}$ treatment had a $\mathrm{pH}$ of $8.02 \pm 0.08$, while controls remained at $7.25 \pm 0.01$.

\section{Discussion}

Nitrate treatment was studied in different concentrations and treatment frequencies through three different experiments. We also evaluated the combination of nitrate with a probiotic strain. Nitrate addition was shown to be a better curative solution to control $\mathrm{H}_{2} \mathrm{~S}$ accumulation, rather than a preventive one. Nitrate amended treatments $\left(12.5 \mathrm{mg} / \mathrm{L}\right.$.day $\left.\mathrm{NO}_{3}{ }^{-}\right)$decreased accumulated $\mathrm{H}_{2} \mathrm{~S}$ in the headspace for about $90 \%$ compared to the controls. Adding denitrifying bacterial strains for anoxic degradation of organic matter did not have an additional impact, since supplemented nitrate was quickly removed by the present microbial community.

\subsection{Frequent nitrate addition could decrease accumulated $\mathrm{H}_{2} \mathrm{~S}$ in the pond as a curative solution}

Denitrification occurs due to development of anaerobic/anoxic zones in the pond. The denitrification rate in a densely stocked fish pond was reported to be $0-0.05 \mathrm{mg} \mathrm{NO}-\mathrm{N} / \mathrm{L} . \mathrm{h}$ during the first 3 months after stocking, yet, later this rate increased to $0.2 \mathrm{mg} \mathrm{NO}_{3}-\mathrm{N} / \mathrm{L} . \mathrm{h}$ (thus $21.8 \mathrm{mg} \mathrm{NO}_{3}^{-} / \mathrm{L}$.day ), despite the continuous surface aeration with paddlewheel aerators (Avnimelech and Zohar, 1986). In a recent study, a similar denitrification rate was reported with the fish waste as the electron acceptor, at $4.5 \mathrm{~g}$ $\mathrm{N} / \mathrm{m}^{3}$.day, hence, about $20 \mathrm{mg} \mathrm{NO}{ }^{-} / \mathrm{L}$.day in a marine recirculating aquaculture system (RAS) microcosm (He et al., 2018). In the present study, a simulation of anaerobic zones in the pond was induced through high input of organic material and replacement of headspace air with nitrogen gas.

Addition of nitrate had only a transient effect to control sulphide accumulation, since its production quickly recovered when all supplemented nitrate was removed. Similar results were obtained by Okabe et al. (2003) and Schwermer et al. (2010), where the in situ sulphide production quickly came back to the initial levels following $\mathrm{NO}_{3}{ }^{-}$depletion. High amounts of nitrate requirements in the anaerobic zones also confirm that in the current study, despite the frequent addition of nitrate through every 4 days pulses, was insufficient until the majority of sulphate was reduced. It might be that SRB activity continued despite nitrate addition, because although the preferential use of nitrate by SRB is possible in many 
systems since nitrate reduction is thermodynamically more favourable, some species of SRB such as Desulfovibrio desulfuricans use sulphate over nitrate when both of the electron acceptors are present in excess (Dalsgaard and Bak, 1994; Marietou, 2009). For this metabolic preference, Sousa et al. (2017) proposed that $D$. desulfuricans activates additional pathways involving amino acid and/or protein biosynthesis to adapt to nitrate medium, whereas in the presence of sulphate the bacterium expresses predominantly the proteins required for its constitutive energy metabolism. For the current study, we speculate that the addition of nitrate did not kill SRB, but rather induced interspecies competition and after the majority of the sulphate was consumed, it enhanced the oxidation of produced $\mathrm{H}_{2} \mathrm{~S}$ as alternative electron donor.

Nitrate addition was shown to induce interspecies competition for common carbon source (i.e., acetate) between SRB and heterotrophic nitrate reducing bacteria in numerous studies mainly targeting microbial corrosion problems (Eckford and Fedorak, 2002; Okabe et al., 2003; Hubert and Voordouw, 2007; Gittel et al., 2009). Apart from toxicity of organic acids to the aquatic environment (Richardson and Gangolli, 1992), these short chain fatty acids also serve as primary substrates for SRB activity. In this study, nitrate addition decreased accumulated acetate and propionate to trace amounts compared to the control. Enhancement of denitrification might have oxidized these short chain fatty acids avoiding their further uptake by SRB to produce $\mathrm{H}_{2} \mathrm{~S}$.

Besides organic acids, the produced $\mathrm{H}_{2} \mathrm{~S}$ could also serve as electron donor for the denitrifiers. The $\mathrm{NO}_{3} / \mathrm{S}^{2-}$ ratio might play a role on formation of intermediate and final degradation of products for the chemolithotrophic reaction (Cardoso et al., 2006). In this study, since in most cases nitrate appears to be limiting for the ratios of $\mathrm{NO}_{3}$ consumed $/ \mathrm{H}_{2} \mathrm{~S}_{\text {consumed, }}$, it was consistent with the denitrification linked to partial oxidation of $\mathrm{H}_{2} \mathrm{~S}$ to elemental sulphur $\left(\mathrm{S}^{\circ}\right)$ rather than sulphate. During the decrease of accumulated $\mathrm{H}_{2} \mathrm{~S}$, it was observed with a yellowish colour with colloidal precipitate turbidity in the liquid phase of the incubation vials. Also increasing $\mathrm{pH}$ in the nitrate treated samples indicated an incomplete oxidation of sulphide to $\mathrm{S}^{0}$ rather than $\mathrm{SO}_{4}{ }^{2-}$ (pH neutral) (Sayama et al., 2005; Kamp et al., 2006). Later, at the end of the incubation time, this colour disappeared without any significant increase in sulphate concentrations, possibly to form polysulphides. 
Yet in real pond conditions, natural accumulation of waste is much slower, since the input feed gradually increases depending on the growing shrimp size. Then the formation of anaerobic zones in the pond would be also slower and should require less nitrate addition in practice. This might make preventive measures more effective, since added nitrate would be sufficient for oxidizing organic matter at least in the first stages after stocking.

\subsection{Nitrate addition increases $\mathrm{pH}$ and might lead to sulphur speciation}

Nitrate addition stimulates the denitrification process in which $\mathrm{OH}^{-}$ions are produced in proportion to amount of nitrate reduced, thereby resulting a higher $\mathrm{pH}$. This was also reported in previous fish pond studies (Pavek, 1998; Chainark, 2008). In this study, higher $\mathrm{pH}$ values in nitrate treated samples were recorded. Pulse dose treatments above $50 \mathrm{mg} / \mathrm{L} \mathrm{NO}_{3}{ }^{-}$resulted in $\mathrm{pH}$ values above 8 , while the controls remained around $\mathrm{pH}$ 7.2-7.4. These values were similar to recommended levels, since the optimum $\mathrm{pH}$ range for shrimp culture is 7.5 to 8.5 (Roy et al., 2011).

After $\mathrm{H}_{2} \mathrm{~S}$ accumulated and reached steady state values, the supplemented nitrate partially removed the produced $\mathrm{H}_{2} \mathrm{~S}$ through sulphur speciation, due to the increased $\mathrm{pH}$ resulting from denitrification. The $\mathrm{H}_{2} \mathrm{~S}$ might have been also partially removed through oxidation of produced $\mathrm{H}_{2} \mathrm{~S}$ to elemental sulphur (Cai et al., 2017). This was also confirmed by an additional test where the impact of nitrate was compared to $\mathrm{NaOH}$ addition after $\mathrm{H}_{2} \mathrm{~S}$ accumulation occurs. In this comparative test, $\mathrm{NO}_{3}{ }^{-}$addition showed a greater decrease in produced $\mathrm{H}_{2} \mathrm{~S}$ than $\mathrm{NaOH}$ addition, thus surpassing the impact of sulphur speciation through $\mathrm{pH}$ change.

\subsection{Addition of extra denitrifying strains did not improve the water quality parameters}

Bacillus species have been used in dietary supplements and for disease control in shrimp aquaculture for over decades (Hong et al., 2005; Wang, 2007; NavinChandran et al., 2014; Sha et al., 2016; Llario et al., 2019). The use of probiotics to prevent pond bottom deterioration has been suggested in literature, but so far no high quality scientific proof is available on their potential (Martinez Cruz et al., 2012., Boyd, 2014). Due to its denitrification potential, we tested B. licheniformis at $10^{7} \mathrm{CFU} / \mathrm{mL}$ in combination with a nitrate treatment to enhance anoxic conversion of the pond bottom waste. However, the addition of this probiotic strain did not enhance removal of accumulated $\mathrm{H}_{2} \mathrm{~S}$ or organic acids more 
than the sole nitrate treatment. Since supplemented nitrate was quickly removed from the system during all of the tests, this was probably because intrinsic capacity of denitrification in this study was high enough.

It is also possible that addition of the probiotic strain in such a harsh environment with high organic material and anaerobic conditions did not work for the waste management. Addition of probiotic strains also did not cause further increase in $\mathrm{pH}$ apart from the impact of nitrate treatment. This also supports the study of Hostins et al. (2017) in which probiotic application did not change water quality parameters, such as $\mathrm{pH}$, water temperature, dissolved oxygen, salinity or alkalinity.

\section{Conclusion}

Nitrate amendment in simulated shrimp aquaculture pond system showed a potential to control $\mathrm{H}_{2} \mathrm{~S}$ accumulation that poses a lethally toxic risk during the growth of the shrimp. The mechanism of the nitrate treatment was shown to work better as a curative solution to control $\mathrm{H}_{2} \mathrm{~S}$ accumulation, rather than preventive, and frequent addition to provide $12.5 \mathrm{mg} / \mathrm{L}$.day $\mathrm{NO}_{3}{ }^{-}$was observed to be a better strategy. Moreover, addition of the probiotic did not show an additional impact to control $\mathrm{H}_{2} \mathrm{~S}$ accumulation than sole nitrate addition.

The results of this study can contribute to understand the capacity and mechanism of curative and preventive nitrate treatment to control $\mathrm{H}_{2} \mathrm{~S}$ accumulation in the shrimp ponds, which is currently considered a critical problem in the shrimp culture.

\section{Acknowledgements}

Funda Torun is a pre-doctoral researcher supported by Baekeland mandate (IWT-Vlaanderen) through the beneficiary as INVE Technologies N.V. Jo De Vrieze is supported as postdoctoral fellow from the Research Foundation Flanders (FWO-Vlaanderen). Special thanks to Laboratory of Aquaculture and Artemia Reference Center, UGent for providing shrimp feed (Crevetec Grower 2) and faeces. Thanks to INVE Aquaculture for their support in the experimental use of the probiotic strain. The authors would also like to thank Greet Van de Velde, Xiaona Hu and Eleftheria Ntagia for their support during the analysis of the samples. 
Antony, S.P., Philip, R., 2006. Bioremediation in Shrimp Culture Systems. NAGA, WorldFish Center

Avnimelech, Y., Zohar, G., 1986. The effect of local anaerobic conditions on growth retardation in aquaculture systems. Aquaculture 58, 167-174. 220, 549-567.

Boyd, C. E., 1989. Water quality management and aeration in shrimp farming. 2nd ed. Alabama Fisheries and Allied Aquacultures Departmental. Agricultural Experiment Station. Auburn University, Alabama, USA.

Boyd, C.E., 1998. Pond water aeration systems. Aquaculture Engineering 18, 9-40.

Boyd, C.E. ,2003. Bottom soil and water management in shrimp ponds. Journal of Applied Aquaculture 13, 11-33.

Boyd, C.E., 2014. Relationships between pond bottom soil management and water quality in shrimp culture ponds. World Aquaculture Society conference, Adelaide, Australia.

Burford, M.A., Peterson, E.I., Baiano, J.C.F., Preston, N.P., 1998. Bacteria in shrimp pond sediments: their role in mineralizing nutriens and some suggested sampling strategies. Aquaculture Research 29, 843-849.

Cai, J., Zheng, P., Qaisar, M., Zhang, J., 2017. Elemental sulfur recovery of biological sulfide removal process from wastewater: A review, Critical Reviews in Environmental Science and Technology, 47:21, 2079-2099.

Cardoso R. B., Sierra-Alvarez R., Rowlette P., Flores E. R., Gómez J., Field J. A., 2006. Sulfide oxidation under chemolithoautotrophic denitrifying conditions. Biotechnoogy and. Bioengineering $951148-1157$. pond studies. Doctoral Dissertation, Auburn University, Auburn, Alabama, USA. 
Chainark, S., Boyd, C.E., 2010. Water and Sediment Quality, Phytoplankton Communities, and Channel Catfish Production in Sodium Nitrate-Treated Ponds. Journal of Applied Aquaculture 22: 2, 171-185. Chen, H.C., 1985. Water quality criteria for farming the grass shrimp, Penaeus monodon in: Proceedings of the First International Conference on the Culture of Penaid Prawns/ Shrimps, edited by Y, Take, J.H.Primavera and J.A. Liobrea, pp: 165.

Christianson, L., Lepine, C., Tsukuda, S., Saito, K., Summerfelt, S., 2015. Nitrate removal effectiveness of fluidized sulfur-based autotrophic denitrification biofilters for recirculating aquaculture systems Aquacultural Engineering 68 , 10-18.

Dalsgaard, T., Bak, F., 1994. Nitrate reduction in a sulfate-reducing bacterium,Desulfovibrio desulfuricans, isolated from rice paddy soil: sulphide inhibition, kinetics, and regulation. Applied Environmental Biology 60, 291-297.

Eckford, R.E., Fedorak, P.M., 2002. Planktonic nitrate-reducing bacteria and sulfate reducing bacteria in some Western Canadian oil field waters. Journal of Industrial Microbiology and Biotechnology 29, 83-92.

FAO, 2018. The State of World Fisheries and Aquaculture 2018 - Meeting the sustainable development goals. Rome. Licence: CC BY-NC-SA 3.0 IGO.

Gittel, A., Sorenson, K.B., Skovhus, T.L., Ingvorsen, K., Schramm, A., 2009. Prokaryotic community structure and sulfate reducer activity in water from high temperature oil reservoirs with and without nitrate treatment, Applied Environmental Microbiology 75, 7086-7096.

Greene, E.A., Brunelle, V., Jenneman, G.E., Voordouw, G., 2006. Synergistic inhibition of microbial sulfide production by combinations of the metabolic inhibitor nitrite and biocides. Applied Environmetal Microbiology, 7897-7901.

He Q., Zhang, D., Main, K., Feng, C., Ergas, S.J., 2018. Biological denitrification in marine aquaculture systems: A multiple electron donor microcosm study. Bioresource Technology 263, 340-349.

Hong, H.A., Duc, L.H., Cutting, S.M., 2005. The Use of Bacterial Spore Formers as Probiotics. FEMS Microbiology Reviews 29, 813-835. 
Hostins, B., Lara, G., Decamp, O., Cesar, D.E., Wasielesky W. Jr., 2017. Efficacy and variations in bacterial density in the gut of Litopenaeus vannamei reared in a BFT system and in clear water supplemented with a commercial probiotic mixture. Aquaculture 480, 58-64.

Hubert, C., Voordouw, G., 2007. Oil field souring control by nitrate reducing Sulfurospirillum spp. that outcompete sulfate-reducing bacteria for organic electron donors. Applied Environmental Microbiology 73, 2644-2652.

Hung, L.T., Quy, O.M., 2013. On farm feeding and feed management in whiteleg shrimp (Litopenaeus vannamei) farming in Viet Nam. In M.R. Hasan and M.B. New, eds. On-farm feeding and feed management in aquaculture. FAO Fisheries and Aquaculture Technical Paper No. 583. Rome, FAO. pp. 337-357.

Joye, S.B., Hollibaugh, J.T., 1995. Influence of sulfide inhibition of nitrification on nitrogen regeneration in sediments. Science 270, 623-625.

Kamp, A., Stief , P \& Schulz-Vogt, H.N., 2006. Anaerobic sulfide oxidation with nitrate by a freshwater Beggiatoa enrichment culture. Applied Environmental Microbiology 72, 4755-4760.

Kim, J.K., Park, K.J., Cho, K.S., Nam, S.W., Park, T.J., Bajpai, R., 2005. Aerobic nitrification, denitrification by heterotrophic Bacillus strains. Biosource Technology 96, 1897-1906.

Li, K., Zheng, T., Tian, Y., Xi, F., Yuan, J., Zhang, G., Hong, H., 2007. Biotechnology Letters 29, 535530.

Llario, F., Falco, S., Sebastiá-Frasquet, M.-T.; Escrivá, J., Rodilla, M., Poersch, L.H., 2019. The Role of Bacillus amyloliquefaciens on Litopenaeus vannamei. During the Maturation of a Biofloc System. Journal of Marine Science and Engineering 7, 228.

Marietou, A., Griffiths, L., Cole, J., 2009. Preferential reduction of thermodynamically less favourable electron acceptor, sulfate, by a nitrate reducing strain of sulfate reducing bacterium, Desulfovibrio desulfuricans 27774. Journal of Bacteriology 191:3, 882-889.

Martinez Cruz, P., Ibanez, A.L., Monroy Hermisillo, O.A., Ramirez Saad, H.C. (2012). Use of probiotics in aquaculture. ISRN Microbiology, 2012: 916845. 
NavinChandran, M., Iyapparaj, P., Moovendhan, S., Ramasubburayan, R., Prakash, S., Immanuel, G., Palavesam, A., 2014. Influence of probiotic bacterium Bacillus cereus isolated from the gut of wild shrimp Penaeus monodon in turn as a potent growth promoter and immune enhancer in P. monodon. Fish \& Shellfish Immunology 36, 38-45.

Okabe, S., Santegoeds, C.M., De Beer, D., 2003. Effect of nitrite and nitrate on in-situ sulfide production in an activated sludge immobilized agar gel film as determined by use of microelectrodes. Biotechnology and Bioengineering 81:5, 570-577.

Panakorn, S., 2016. $\mathrm{H}_{2} \mathrm{~S}$ toxicity-silent kiler. AQUA CULTURE Asia Pacific, issue: March-April.

Pavek, R. E., 1998. Effect of sodium nitrate enrichment on water quality variables, bottom sediments and catfish production in earthern ponds. MS Thesis, Auburn University, Auburn, Alabama, USA.

Pratwitwilaikul, O., Limsuwan, C., Taparhudee, W., Chuchird, N., 2006. A comparison of rearing pacific white shrimp (Liptopenaeus vannamei Boone, 1931) in earthen ponds and in lined ponds with polyethylene. Kasetsart Journal 40, 167-171.

Roy, S., Rahman, M.M., Sarkar, S.N., Mondal, B., 2011. Training Manual On Improved Shrimp Culture in Gher. Cereal Systems Initiative for South Asia in Bangladesh (CSISA-Bangladesh), World Fish Center.

Richardson, M.L., Gangolli, S., 1992. The Dictionary of Substances and their Effects. Royal Society of Chemistry, Cambridge.

Sayama, M., Risgaard-Petersen, N., Nielsen, L.P., Fossing, H., Christensen, P.B., 2005. Impact of bacterial $\mathrm{NO}_{3}{ }^{-}$transport on sediment biogeochemistry. Applied Environmental Microbiology 71, 75757577.

Schwermer, C.U., Ferdelman, T.G., Stief, P., Gieseke. A., Rezakhani, N., Van Rijn, J., De Beer, D., Schramm, A., 2010. Effect of nitrate on sulfur transformations in sulfidogenic sludge of a marine aquaculture biofilter. FEMS Microbiology Ecology 72, 476-484.

Sha, Y., Wang, L., Liu, M., Jiang, K., Xin, F., Wang, B., 2016. Effects of lactic acid bacteria and the corresponding supernatant on the survival, growth performance, immune response and disease resistance of Litopenaeus vannamei. Aquaculture 452, 28-36. 
481 Sousa, J.R., Silveira, C.M., Fontes, P., Roma-Rodrigues, C., Fernandes, A.R., Van Driessche, G., 482 Devreese, B., Moura, I., Moura, J.J.G, Almeida, M.G., 2017. Understanding the response 483 of Desulfovibrio desulfuricans ATCC 27774 to the electron acceptors nitrate and sulfate - biosynthetic 484 costs modulate substrate selection. Biochimica et Biophysica Acta 1865, 1455-1469.

485 Suo, Y., Li, E., Li, T., Jia Y., Qin, J.G., Gu, Z., Chen, L. (2017). Response of gut health and microbiota 486 to sulfide exposure in Pacific white shrimp Litopenaeus vannamei. Fish \& Shellfish Immunology 63, 8748796.

488 Tal, Y., Schreier, H.J., Sowers, K.R., Stubblefield, J.D., Place, A.R., Zohar, Y., 2009. Environmentally 489 sustainable land-based marine aquaculture. Aquaculture 286 (1-2), 28-35.

490 Vismann, B., 1996. Sulfide species and total sulfide toxicity in the shrimp Crangon crangon. Journal 491 of Experimental Marine Biology and Ecology 204, 141-154.

492 Wang, Y.B., 2007. Effect of probiotics on growth performance and digestive enzyme activity of the 493 shrimp Penaeus vannamei. Aquaculture 269, 259-264. 
496 Table 1. The overview of experiments conducted

\begin{tabular}{|c|c|c|c|c|}
\hline $\begin{array}{c}\text { Experiment } \\
\text { name }\end{array}$ & $\begin{array}{l}\text { Amount of } \\
\text { nitrate } \\
\text { tested } \\
(\mathrm{mg} / \mathrm{L})\end{array}$ & $\begin{array}{l}\text { Timing of } \\
\text { nitrate } \\
\text { addition }\end{array}$ & $\begin{array}{c}\text { Other } \\
\text { treatments } \\
\text { used in } \\
\text { comparison or } \\
\text { combination }\end{array}$ & $\begin{array}{c}\text { Waste input } \\
\text { (In total volume of } 300 \mathrm{~mL} \\
\text { instant ocean) }\end{array}$ \\
\hline $\begin{array}{l}\text { Dual dose } \\
\text { nitrate } \\
\text { treatment }\end{array}$ & $50,100,200$ & $\begin{array}{l}\text { On day } 0 \\
\text { and } 14\end{array}$ & - & $\begin{array}{c}392 \pm 1 \mathrm{mg} \text { feed }+12.9 \mathrm{~mL} \text { faeces } \\
(4 \% \mathrm{TS}, \text { hence } 0.516 \mathrm{~mL})\end{array}$ \\
\hline $\begin{array}{c}\text { Multiple dose } \\
\text { nitrate } \\
\text { treatment }\end{array}$ & $12.5,25,50$ & $\begin{array}{l}\text { Every } 4 \\
\text { days }\end{array}$ & - & $\begin{array}{c}392 \pm 1 \mathrm{mg} \text { feed }+13.87 \mathrm{~mL} \text { faeces } \\
(3.7 \% \mathrm{TS}, \text { hence } 0.514 \mathrm{~mL})\end{array}$ \\
\hline $\begin{array}{c}\text { Microbially } \\
\text { assisted } \\
\text { nitrate } \\
\text { treatment }\end{array}$ & 50 & $\begin{array}{c}\text { Every } 4 \\
\text { days }\end{array}$ & $\begin{array}{c}\text { Bacillus } \\
\text { licheniformis at } \\
10^{7} \mathrm{CFU} / \mathrm{mL}\end{array}$ & $\begin{array}{c}392 \pm 1 \mathrm{mg} \text { feed }+11.34 \mathrm{~mL} \text { faeces } \\
(4.6 \% \mathrm{TS} \text {, hence } 0.521 \mathrm{~mL})\end{array}$ \\
\hline $\begin{array}{c}\text { Nitrate } \\
\text { treatment in } \\
\text { comparison } \\
\text { with } \mathrm{NaOH}\end{array}$ & 200 & On day 5 & $\begin{array}{c}\mathrm{NaOH} \text { at } 320 \\
\mathrm{mg} / \mathrm{L}\end{array}$ & $\begin{array}{c}392 \pm 1 \mathrm{mg} \text { feed }+11.34 \mathrm{~mL} \text { faeces } \\
(4.6 \% \mathrm{TS}, \text { hence } 0.521 \mathrm{~mL})\end{array}$ \\
\hline
\end{tabular}


499 Table 2. The $\mathrm{pH}$ and concentrations of the organic acids after incubation time for the dual dose nitrate 500 treatment. Mean values and standard deviations of the biological replicates are reported.

\begin{tabular}{c|c|c|c|c|c|c} 
Treatments & $\mathbf{p H}$ & $\begin{array}{c}\text { Formate } \\
(\mathbf{m M})\end{array}$ & $\begin{array}{c}\text { Acetate } \\
(\mathbf{m M})\end{array}$ & $\begin{array}{c}\text { Propionate } \\
(\mathbf{m M})\end{array}$ & $\begin{array}{c}\text { Butyrate } \\
(\mathbf{m M})\end{array}$ & $\begin{array}{c}\text { Total } \\
\text { organic } \\
\text { acids } \\
(\mathbf{m M})\end{array}$ \\
\hline $\mathbf{N - 0}$ & $7.07 \pm 0.01$ & 0.04 & $2.92 \pm 0.26$ & $0.58 \pm 0.08$ & $0.04 \pm 0.03$ & $3.58 \pm 0.37$ \\
\hline $\mathbf{N - 5 0}$ & $7.16 \pm 0.01$ & 0.05 & $2.64 \pm 0.25$ & $0.22 \pm 0.03$ & $0.03 \pm 0.02$ & $2.94 \pm 0.35$ \\
\hline $\mathbf{N}-100$ & $7.27 \pm 0.01$ & 0.06 & $1.24 \pm 0.12$ & $0.12 \pm 0.01$ & $0.03 \pm 0.02$ & $1.45 \pm 0.15$ \\
\hline $\mathbf{N}-200$ & $7.40 \pm 0.02$ & 0.08 & $0.59 \pm 0.39$ & $0.03 \pm 0.01$ & $0.03 \pm 0.03$ & $0.73 \pm 0.43$
\end{tabular}

501

502 
Table 3. The $\mathrm{pH}$ and concentrations of the organic acids after incubation time for the multiple dose nitrate treatment. Mean values and standard deviations of the biological replicates are reported.

\begin{tabular}{c|c|c|c|c|c|c} 
Treatments & $\mathbf{p H}$ & $\begin{array}{c}\text { Formate } \\
(\mathbf{m M})\end{array}$ & $\begin{array}{c}\text { Acetate } \\
(\mathbf{m M})\end{array}$ & $\begin{array}{c}\text { Propionate } \\
(\mathbf{m M})\end{array}$ & $\begin{array}{c}\text { Butyrate } \\
(\mathbf{m M})\end{array}$ & $\begin{array}{c}\text { Total } \\
\text { organic } \\
\text { acids } \\
(\mathbf{m M})\end{array}$ \\
\hline $\mathbf{N - 0}$ & $7.45 \pm 0.05$ & $0.02 \pm 0.02$ & $2.48 \pm 0.41$ & $0.85 \pm 0.14$ & $0.07 \pm 0.03$ & $3.42 \pm 0.6$ \\
\hline $\mathbf{N - 1 2 . 5}$ & $7.69 \pm 0.01$ & $0.08 \pm 0.05$ & $1.29 \pm 0.22$ & $0.16 \pm 0.03$ & $0.05 \pm 0.01$ & $1.58 \pm 0.31$ \\
\hline $\mathbf{N}-25$ & $7.90 \pm 0.01$ & 0 & $0.06 \pm 0.08$ & 0 & 0.04 & $0.1 \pm 0.08$ \\
\hline $\mathbf{N}-50$ & $8.78 \pm 0.03$ & 0 & $0.06 \pm 0.04$ & 0 & 0 & $0.06 \pm 0.04$
\end{tabular}

506 
Table 4. The $\mathrm{pH}$ and concentrations of the organic acids after incubation time for the microbially assisted nitrate treatment. Mean values and standard deviations of the biological replicates are reported.

\begin{tabular}{c|c|c|c|c|c|c} 
Treatments & $\mathbf{p H}$ & $\begin{array}{c}\text { Formate } \\
(\mathbf{m M})\end{array}$ & $\begin{array}{c}\text { Acetate } \\
(\mathbf{m M})\end{array}$ & $\begin{array}{c}\text { Propionate } \\
(\mathbf{m M})\end{array}$ & $\begin{array}{c}\text { Butyrate } \\
(\mathbf{m M})\end{array}$ & $\begin{array}{c}\text { Total } \\
\text { organic } \\
\text { acids } \\
(\mathbf{m M})\end{array}$ \\
\hline Control & $7.26 \pm 0.03$ & 0 & $2.07 \pm 0.1$ & $1.03 \pm 0.20$ & $0.08 \pm 0.01$ & $3.18 \pm 0.31$ \\
\hline $\mathbf{N}$ & $8.09 \pm 0.03$ & 0 & 0 & 0 & $0.01 \pm 0.02$ & $0.01 \pm 0.02$ \\
\hline $\mathbf{B}$ & $7.22 \pm 0.02$ & $0.04 \pm 0.03$ & $2.74 \pm 0.16$ & $1.27 \pm 0.08$ & 0.08 & $4.09 \pm 0.27$ \\
\hline $\mathbf{N + B}$ & $8.08 \pm 0.03$ & 0 & 0 & 0 & $0.02 \pm 0.02$ & $0.02 \pm 0.02$
\end{tabular}

511 
Figure 1. Concentration of $\mathrm{H}_{2} \mathrm{~S}(\mathrm{~A})$ and $\mathrm{CO}_{2}(\mathrm{~B})$ in the headspaces of the vials and concentration of nitrate $\left(\mathrm{NO}_{3}-\mathrm{N}\right)(\mathrm{C})$, and sulphate $\left(\mathrm{SO}_{4}\right)(\mathrm{D})$ in the liquid phase for the control (N0) and treatments at 50 $(\mathrm{N}-50), 100(\mathrm{~N}-100)$ and $200(\mathrm{~N}-200) \mathrm{mg} / \mathrm{L} \mathrm{NO}_{3}{ }^{-}$. Nitrate was added on day 0 and day 14 . Values represent mean of biological replicates, and error bars represent standard deviation of the biological replicates. Timing of nitrate addition is indicated by $*$ symbols.

Figure 2. Concentration of $\mathrm{H}_{2} \mathrm{~S}(\mathrm{~A})$ and $\mathrm{CO}_{2}(\mathrm{~B})$ in the headspace of the vials and nitrate $\left(\mathrm{NO}_{3}-\mathrm{N}\right)(\mathrm{C})$, and sulphate $\left(\mathrm{SO}_{4}\right)(\mathrm{D})$ in the liquid phase for the control (N0) and treatments at $12.5(\mathrm{~N}-12.5), 25(\mathrm{~N}-$ $25)$ and $50(\mathrm{~N}-50) \mathrm{mg} / \mathrm{L} \mathrm{NO}_{3}{ }^{-}$. Nitrate was added every 4 days during 56 days of incubation. Values represent mean of biological replicates, and error bars represent standard deviation of the biological replicates. Timing of nitrate addition is indicated by * symbols.

526

Figure 3. Concentration of $\mathrm{H}_{2} \mathrm{~S}(\mathrm{~A})$ and $\mathrm{CO}_{2}(\mathrm{~B})$ in the headspace of the vials and nitrate $\left(\mathrm{NO}_{3}-\mathrm{N}\right)(\mathrm{C})$, and sulphate $\left(\mathrm{SO}_{4}\right)(\mathrm{D})$ in the liquid phase for the control (Control), $50 \mathrm{mg} / \mathrm{L} \mathrm{NO}_{3}{ }^{-}$treatment $(\mathrm{N}), 10^{7}$ $\mathrm{CFU} / \mathrm{mL}$ Bacillus licheniformis treatment $(\mathrm{B})$ and their mixture thereof $(\mathrm{N}+\mathrm{B})$. Nitrate was added every 4 days during 44 days of incubation (indicated by *). Values represent mean of biological replicates and error bars represent standard deviation of the biological replicates. 